\section{Blood urea}

\section{Normal values in early infancy related to feeding practices}

Urea, as one of the end products of protein metabolism, constitutes a major part of the renal solute load (Fomon, 1967a), and in the young infant its concentration in the blood reflects the combined effect of dietary protein intake, the degree of hydration, and the functional maturity of the kidney (Fomon, 1967b; Edelmann and Spitzer, 1969).

Current infant feeding practices in the United Kingdom favour artificial milk formulae and the early introduction of solid foods at the expense of breast feeding (Taitz, 1971; Shukla et al., 1972). Such practices have been shown to be associated with a considerably higher protein intake than is currently recommended (Shukla et al., 1972). These facts prompted us to measure the blood urea of young healthy infants with particular reference to their pattern of feeding.

\section{Patients and methods}

Sixty-one healthy infants aged between 1 and 3 months were studied. This was an unselected sample of infants attending a Cardiff Local Health Authority Clinic. Capillary blood was obtained by heel prick between 2.00 p.m. and 4.00 p.m. The time interval between sampling and the previous feed was variable, but in no instance was it less than one hour. Blood urea was determined by the Bertholet reaction. A feeding history was obtained from the mothers, and as a result the infants were divided into three groups. Group A were those wholly breast fed, group B were being fed on modified cow's milk formulae alone, and group $\mathrm{C}$ were infants who had already been introduced to a number of commercially available solid foods (mainly infant cereals and various instant or strained dinners) as well as being maintained on their artificial milk formulae. Student's ' $t$ ' test was applied to determine the statistical significance of the mean values for blood urea between the three groups of infants.

\section{Results}

Individual blood urea concentrations with mean values $( \pm S E)$ for the three groups are shown diagrammatically in the Fig. The Table summarizes the statistical data.

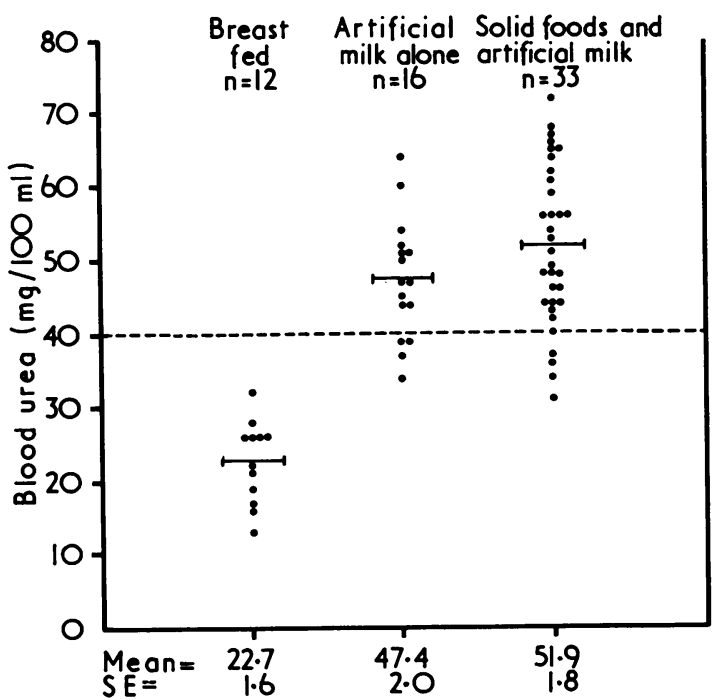

Fig.-Blood urea levels in 61 healthy infants aged 1 to 3 months.

In the breast-fed infants (group $A$ ) the mean blood urea $(22.7 \mathrm{mg} / 100 \mathrm{ml})$ was lower $(P<0.001)$ than in group $B(47 \cdot 4 \mathrm{mg} / 100 \mathrm{ml})$ and group $C(51 \cdot 9$ $\mathrm{mg} / 100 \mathrm{ml}$ ). The difference between groups $B$ and $C$ was not significant $(P>0.05)$. Of the individual values in the breast-fed group, none was above $\mathbf{4 0}$ $\mathrm{mg} / 100 \mathrm{ml}$, the accepted upper limit of normal. However, in the infants fed artificial milk formulae alone, 12 observations ( $75 \%$ of the total number) were above $40 \mathrm{mg} / 100 \mathrm{ml}$; and in those infants on a mixed diet, 29 ( $88 \%$ of the total observations) were above this level. When compared with the breast-fed group, both these proportions were highly significant $(P<0.001)$ on each occasion. The difference between groups $B$ and $C$ did not reach a level of significance.

\section{Discussion}

Human breast milk has a much lower protein content than cow's milk ( $1 \cdot 1 \mathrm{~g} / 100 \mathrm{ml}$ compared with about $3.3 \mathrm{~g} / 100 \mathrm{ml}$ ) (Macy and Kelly, 1961), and protein contributes only 6 to $7 \%$ of the total calorie content (Fomon, 1967b). Since bottle-fed infants have a much greater protein intake than 
TABLE

Statistical analysis by Student's ' $t$ ' test of blood urea levels in 61 healthy infants aged 1 to 3 months

\begin{tabular}{|c|c|c|c|c|}
\hline \multirow[b]{2}{*}{ Infant group } & \multirow[b]{2}{*}{ No. } & \multirow{2}{*}{$\frac{\text { Blood urea }(\mathrm{mg} / 100 \mathrm{ml})}{\text { Mean } \pm \mathrm{SE}}$} & \multicolumn{2}{|c|}{ Individual values $>40 \mathrm{mg} / 100 \mathrm{ml}$} \\
\hline & & & No. & $\%$ of total observations \\
\hline $\begin{array}{c}\text { A } \\
\text { Breast fed } \\
\text { B } \\
\text { Artificial milk } \\
\text { alone } \\
\text { C } \\
\text { Artificial milk } \\
\text { + solid foods }\end{array}$ & $\begin{array}{l}12 \\
16 \\
33\end{array}$ & $\begin{array}{l}22 \cdot 7 \pm 1 \cdot 6^{\star} \\
47 \cdot 4 \pm 2 \cdot 0 \dagger\end{array}$ & $\begin{array}{r}0 \\
12 \\
29\end{array}$ & $\begin{array}{r}0 \ddagger \\
75 \S \\
88\end{array}$ \\
\hline
\end{tabular}

ॠWhen compared with group $B$ and group $C: P<0.001(t=9.7)$ and $P<0.001(t=11 \cdot 5)$, respectively. +When compared with group $C: P>0.05(t=1 \cdot 6)$.

$\ddagger$ When compared with group $B$ and group $C: P<0.001(t=6.9)$ and $P<0.001(t=15 \cdot 5)$, respectively.

SWhen compared with group $C: P>0.05(t=1 \cdot 1)$.

those who are breast fed, it is perhaps not surprising that the mean blood urea in our breast-fed infants was much lower than in the two groups of infants who were artificially fed, particularly since blood urea concentration closely reflects dietary protein intake (Fomon, 1967b). However, to find such a high proportion of observations above $40 \mathrm{mg} / 100$ $\mathrm{ml}$ in both groups of infants who were artificially fed is unexpected. It seems likely that these high urea values in healthy infants are the result of very high dietary protein intakes at a time when the ability of the still relatively immature kidney to withstand the stress of urea loading is limited (Edelmann and Spitzer, 1969). These observations appear to confirm the findings of Shukla et al. (1972) that protein intake in many young infants at the present time is excessive.

Fomon (1967b) refers to blood urea levels in infants 2 to 4 months old who were fed ad libitum milk formulae with a protein content which provided $20 \%$ of the calorie intake (about three times that of breast milk and similar to unmodified cow's milk). The mean blood urea was only $24 \cdot 3 \mathrm{mg} / 100 \mathrm{ml}$, a value considerably lower than $47.4 \mathrm{mg} / 100 \mathrm{ml}$, which was found in our infants fed milk formulae alone. It is difficult to account for these unusually high values, but they might perhaps reflect the tendency of many mothers to fail to comply with instructions on the milk packets and instead to prepare artificial milk feeds from heaped scoops instead of level scoops (Taitz and Byers, 1972). An increase in dietary protein intake would then be likely with an accompanying rise in blood urea.

Many commercially available foods have a high protein content (Shukla et al., 1972). The infants on a mixed diet might, therefore, have been expected to have an even higher blood urea concentration than those fed on milk formulae alone. However, though in this group the mean blood urea was higher and the number of observations above $40 \mathrm{mg} / 100$ $\mathrm{ml}$ were greater than in the infants on milk formulae, these differences did not reach statistical significance. A possible explanation might be that milk intake is often reduced as the amounts of solids are increased in young infants' diets. Protein intake would then be expected to be similar in both these groups of infants with consequent blood urea concentrations which would, therefore, not differ much from each other.

\section{Summary}

Blood urea was measured in 61 healthy infants aged between 1 and 3 months.

Artificially-fed infants on modified cow's milk formulae, alone or combined with solid foods, had mean values significantly higher than in breast-fed infants, and also well above the accepted upper limit of normal $(40 \mathrm{mg} / 100 \mathrm{ml})$.

Awareness of an infant's feeding habits is essential for the correct interpretation of blood urea concentrations.

We thank Dr. D. J. Anderson, Medical Officer of Health, and all the Public Health Staff of the Roath Court Health Authority Clinic, Cardiff, for their cooperation; Mrs. D. Williams for nursing assistance; Professor O. P. Gray for valuable criticism; Mrs. S. Josty for secretarial help; and all the mothers who so kindly allowed us to study their babies.

\section{REFERENCES}

Edelmann, C. M., Jr., and Spitzer, A. (1969). The maturing kidney. Fournal of Pediatrics, 75, 509.

Fomon, S. J. (1967a). Infant Nutrition, p. 139. Saunders, Philadelphia and London.

Fomon, S. J. (1967b). Infant Nutrition, p. 57. Saunders, Philadelphia and London. 
Macy, I. G., and Kelly, H. J. (1961). Human milk and cow's milk in infant nutrition. In Milk: The Mammary Gland and its Secretion, Vol. II, p. 265 . Ed. by S. K. Kon and A. T. Cowie. Academic Press, New York.

Shukla, A., Forsyth, H. A., Anderson, C. M., and Marwah, S. M. (1972). Infantile overnutrition in the first year of life. A field study in Dudley, Worcestershire. British Medical fournal, 4, 507.

Taitz, L. S. (1971). Infantile overnutrition among artificially fed infants in the Sheffield region. British Medical fournal, 1, 315.

Taitz, L. S., and Byers, H. D. (1972). High calorie/osmolar feeding and hypertonic dehydration. Archives of Disease in Childhood, 47, 257.

D. P. DAvies ${ }^{\star}$ and R. SAUNDERS

Department of Child Health, University Hospital of Wales, Cardiff, and Department of Biochemistry, Llandough Hospital.

*Correspondence to Dr. D. P. Davies, Department of Child Health, University Hospital of Wales, Heath Park, Cardiff CF4 4XN.

\section{Plasma growth hormone response to exercise as diagnostic aid}

The development and application of an exercise test to screen subjects for possible growth hormone (GH) deficiency has recently been described (Buckler, 1972). This depended on estimating the plasma GH level in a single blood sample taken 25 to 30 minutes from the start of a short period of intensive exercise. The results in that report were largely based on experiments conducted on healthy normal individuals, most of whom were postpubertal. Though information about $\mathrm{GH}$ function is of considerable value in adults suspected of hypopituitarism, the greatest application of such a test will be in the investigation of small stature in children. As the test is now being adopted in other centres (Hall, 1972; Jacobs, 1972), it seems advisable to draw attention to its limitations in its present form, and to stress that it is only a screening procedure. This report describes the results of the use of this test in children and young adults of short stature.

\section{Subjects and methods}

Fifty-nine children ( 17 girls and 42 boys) with short stature ( $<3$ rd centile for height) were studied. Most of these were referred for investigation of the shortness of stature, but a few had, in addition, delayed puberty or other features possibly attributable to pituitary insufficiency.

A single venous blood sample was taken 25 to 30 minutes after a short period of intensive exercise. In children sufficiently old and tall, this exercise was performed on a bicycle ergometer, and usually required 5 to 10 minutes hard pedalling. In small children the exercise could take other suitable forms such as running on the flat, up and down stairs, or skipping. The exercise was of sufficient intensity to render the subject breathless and fatigued, but not exhausted. The procedure was usually undertaken during the course of an outpatient visit. This could be at any time of day and the test did not involve fasting, restriction of preceding activity, or other special preparation. Plasma GH levels were measured by a double antibody radioimmunoassay (Buckler, 1970), and values are reported in $\mu U$ of the 1st International Reference Preparation of human growth hormone.

\section{Results}

Table I gives the results. A plasma GH level of $10 \mu \mathrm{U} / \mathrm{ml}$ or above is generally considered to indicate responsiveness. By this criterion, 44 of the 59 children were shown by this exercise test to be capable of releasing GH.

TABLE I

Plasma GH levels after exercise in children of short stature

\begin{tabular}{|c|c|c|c|c|}
\hline \multirow{3}{*}{ Age (yr) } & \multicolumn{4}{|c|}{ No. of children } \\
\hline & \multirow{2}{*}{ Total } & \multicolumn{3}{|c|}{ Plasma GH levels $(\mu \mathrm{U} / \mathrm{ml})$ after exercise } \\
\hline & & $<10$ & $10-20$ & $>20$ \\
\hline $\begin{array}{c}\text { Girls } \\
<10 \\
10-15 \\
15-20 \\
\text { Total } \\
\text { Boys } \\
<10 \\
10-15 \\
15-20 \\
\text { Total }\end{array}$ & $\begin{array}{r}4 \\
11 \\
2 \\
17 \\
13 \\
18 \\
11 \\
42\end{array}$ & $\begin{array}{r}0 \\
3 \\
0 \\
3 \\
6 \\
6 \\
3 \\
3 \\
12\end{array}$ & $\begin{array}{l}2 \\
3 \\
1 \\
6 \\
4 \\
3 \\
1 \\
8\end{array}$ & $\begin{array}{r}2 \\
5 \\
1 \\
8 \\
3 \\
12 \\
7 \\
22\end{array}$ \\
\hline $\begin{array}{l}\text { Total } \\
\text { (Girls and boys) }\end{array}$ & 59 & 15 & 14 & 30 \\
\hline
\end{tabular}

